Vol. 6, No. 2, 2019

https://doi.org/10.23939/eem2019.02.001

UDC 378:336(477)

JEL Classification Code I21

O. Kuzmin

Lviv Polytechnic National University, Ukraine, Doctor, Professor

E-mail: Oleh.Y.Kuzmin@1pnu.ua

ORCID: 0000-0002-6014-6437

M. Yastrubskyy

Lviv Polytechnic National University, Ukraine, Doctor, Professor

E-mail: mypolynet@gmail.com

H. Tsegelyk

Ivan Franko Lviv National University, Ukraine, Doctor, Professor

ORCID: 0000-0002-4934-3181

\title{
MODEL OF DEVELOPMENT AND STATE REGULATION OF ACTIVITY OF HIGHER EDUCATIONAL INSTITUTION (HEI): USING EXPERIENCE IN MANAGEMENT OF LEADING HEI OF EAST ASIA
}

\begin{abstract}
The article studies the positive experience of leading universities in East Asia. The article analyzed the management of the National University of Singapore, which belongs to the strongest higher education in several areas. The University is known as a leading research center in the world, experienced educational institution, which attracts the best students from around the world. Emphasized the high quality of educational services of the University, provided a number of effective factors combine to guarantee obtaining a student in-depth knowledge of the chosen professional direction. It is noted that in Singapore the world built on a British school and these factors that ensure success in education. Attention is focused on a favorable external environment, allowing you to open up internal reserves. The University operates as part of scientific and industrial park, allowing efficient use of funds and to coordinate efforts for the production of high technology products. It is noted that in law the companies participating in the research and development of industrial parks, offered benefits. As a result of the review of the experience of leading universities of East Asia highlighted a number of common features which combine to provide a successful business. The model of building an effective system of higher education in Ukraine is proposed
\end{abstract}

Key words: East Asia, management, the reform of the higher school, model of development of the higher school.

\section{Introduction}

The twenty-first century can rightly be called as a period of rapid changes at global and regional levels. It almost applies to all spheres of public life, especially the economy, science, education. At the same time, such spheres as economic, scientific and educational in our era are inseparable. A technocratic society requires constant education. And the country, a community in which education and science is in a state of neglect, can also lay account with a similar place in the world economy in other words, the role of a serving appendage with limited capacity for functioning, and there is no point to speak about development.

This article is devoted to study of the positive experience of leading higher educational institutions (HEI) of East Asia, that in terms of its potential are entitled to rely on leadership on a global scale in the coming years. The East Asian region is among to number of largest in terms of area and population 


\section{O. Kuzmin, M. Yastrubskyy, H. Tsegelyk}

not only in Asia, but throughout the world. The purpose of the study is to analyze the various factors, which in combination provide a breakthrough in higher education, science, which in turn drives the accelerated social change caused by technological progress. This article describes reasonably attractive aspects of management leading universities of East Asia, which together provide them high ranking positions

Reform of higher education in Ukraine during the years of its independence runs continuously. This is a number of reasons, but generally, it is required challenges. Convert relating to different parts: the ideological direction of higher education, school organization and content, financial support, management organization and so on. It is clear that a wide range of processing needs versatile, making a list of government officials, scientists, interested in the impact of the reforms is rather large. We stopped at the designated research topic in recent years, because during this period offers a new paradigm of higher education in Ukraine, changing stereotypes of high school, his place in society.

Priorities of the government in the field of Education outlined the Minister of Education and Science of Ukraine during a round table discussion dedicated isolation areas in the field of Education, which was included in the medium-term plan of priority actions of the Government by 2020 [1]. Academician of NAS of Ukraine M. Z. Zgurovsky [2] outlined topical issues of concern to the leaders of Ukrainian universities in today's conditions.. The system of autonomous research institutions of Ukraine, their place and role of security in terms of reforming higher education were investigated by the example of leading Ukrainian institutions [3]. Features resource support higher education institutions in the comparative example of leading domestic and foreign universities revealed in an article by prof. $O$. E. Kuzmin. Features of influence contingent of foreign students on the impact of universities and attractive highlights it in the next article [4].

The aim of the article is studies have themes higher education reform Ukraine prompted according to study similar processes in East Asia. By itself, the region becomes more attractive given the rapid pace of development, whereby not only in the economic sphere. The study of the system of management of high school motivated successful promotion to leadership positions leading universities in China, South Korea, Japan, Singapore, Hong Kong. All are members of the fifty best universities in the world.

\section{Experience in management of leading HEI of East Asia}

The reform of higher education in Ukraine belongs to the list of emergency. It is understood authorities, researchers and involved in research and educational activities, ordinary citizens, who themselves learn, or teach their children face such a choice. However the process is progressing rather slowly, faced with a number of difficulties and obstacles. It is clear that Ukraine is not the first faced with such issues to resolve. Those countries that have achieved the educational and scientific sphere important success also appointed solve issues facing the dilemma - which way to go to achieve success. In his article, we turn to the experience of the leading universities of the East Asian region. The reason for this serves their potential ability to convincingly encouraging the study of his rapid promotion to leading positions in the world.

By Asia includes different form of government of the country: the Socialist Republic of China and North Korea, or North Korea; Republic of Mongolia and the Republic of Korea (South Korea), constitutional monarchy Japan, colonies of Great Britain and Portugal - Hong Kong and Macau, and Taiwan[5]. We consider the experience of the development of higher education institutions that now hold high positions in rating.

The largest university city-state in the southwestern part of Asia is the National University of Singapore, established in 1980 through the merger of the University of Singapore and the University Nanyanhu. $\mathrm{He}$ stands originators educational rankings among the best universities in the world and it is considered as the best university in Asia. According Times Higher Education National University of Singapore in the 2016-2017 biennium. 24 took place[6]. University belongs to the strongest higher education in several areas: its three departments make up the top 10 in the world for their professional focus, ahead of such famous institutions as Yale University and King's College London. 
The University is known as a leading research center in the world, experienced educational institution, which attracts the best students from around the world. A special place is the direction of engineering and innovative technologies. Against other schools significantly distinguished departments of chemical engineering, electrical engineering, architecture and civil engineering. In second distinguished faculty of social sciences, including social policy program, and statistics development. In third position supplying business-school of the University of Singapore, which is rightly considered the strongest in the world, through which graduates of different faculties flock here for management skills[7].

The undeniable fact is the scientific potential of the University of Singapore. Extremely high citation index and huge capital with its research in nanotechnology, bioengineering, chemistry and materials science. Quite effective are the Singapore University research in pharmacology and innovative solutions in the fight against incurable diseases. One of the most respected and considered current scientific publications and research staff of educational institutions in the field of environmental problems.

The National University of Singapore (NUS) trained 37.970 students in total population of 5.8 million. The authors aim to promote the studied educational institution, but rather a study of positive experience, thanks to which achieved good results. Singapore - a country in which people are given a good education, enjoy demand in the outside world. Graduates open new avenues for immigration, employment as domestic market is unable to accommodate all outstanding professionals. Nevertheless, a large number of Singapore companies seeking to attract young professionals, achieving this through grants. Strong potential to serve them received high-quality knowledge in immigration allow visitors to gain a foothold in a new place.

NUS diplomas and certificates are recognized internationally, indicating the high professional training. High quality of educational services provided by a number of effective factors combine to guarantee obtaining a student in-depth knowledge of the chosen professional direction. General education in Singapore, built on a British school. Among a number of factors for success in education is worth following.

Firstly, when joining the NUS is rather high competitive selection. Applicant at the highest level should have knowledge of English. Confirmation of the presence serves as IELTS or TOEFL certificate with a score of $92-100$ points, or $6.5-7.0$, respectively, which are necessary when filing. To enter into separate faculties, such as law, medicine, architecture provides for delivery of entrance examinations. Training at NUS is in several languages, including English, considered basic.

Secondly, the NUS has tight control traffic classes. If the total student attendance is less than $90 \%$, or fixed within a week passes without a valid reason the session, he loses student card and sent home.

Thirdly, during the training the students are not permitted to work regardless of the type of work. At the slightest suspicion of engaging in economic activity on the part of immigration services for foreign students, this means graduation and expulsion from the country. Such constraints designed to focus solely towards student's development objective guidance. Fourth, logistics training process creates all conditions for comfortable training.

However, students living in Singapore stands virtually complete lack of dormitories. Usually, Singapore educational institutions contracting with outside organizations that provide public places in their campuses. Fee for a place in the room is an average of $\$ 500$ per month. NUS before it has three student residences with a total capacity of about 7000 people. Students are provided the individual cozy rooms. In addition, on campus are 6 separate halls with a few hundred individual and one bedroom apartments.

NUS is available in a range of sports facilities, soccer fields, swimming pools, tennis courts. At the disposal of students is a rich library, computer club, several cafes. Together these constraints and created favorable conditions for teaching and student accommodation offer adequate educational results.

Analyzing the achievements of Singapore in education and science appropriate to refer to the financial support. Success of NUS heavily linked with a favorable external environment, allowing you 


\section{O. Kuzmin, M. Yastrubskyy, H. Tsegelyk}

to open up internal reserves. The University operates as part of scientific-industrial Park, which is created in the early $80 . \mathrm{XX}$ century for the effective use of financial resources and coordination of efforts on the issue of high technology products. The motivation of the creation of the park was the realization of the task of transforming the city-state into a regional center of information and knowledge-based industries. Special attention was paid to the development of biotechnology, electronics, artificial intelligence, laser technology, robotics technology in the field of informatics and communication. At the industrial park, an area of about 30 hectares, located 5 state research institutes, including NUS, and about 45 industrial corporations. It is the largest development center and leading industrial technology innovation center of the country [8].

Since fiscal year 2010 the Ministry of Finance of Singapore introduced a development program, with a budget priority was the development of the educational sector. The legislation to companies involved in research and development of industrial parks, offered benefits. In particular, half reduced income tax rate of investments in research and development; introduced a preferential tax for the construction and operation of industrial buildings in the industrial park area. That is the state of his versatile side supports not only the development of science and education, and strongly initiate their merging with the production, which involves production of high technology products.

Singapore Guide invested millions of dollars to create a powerful educational network in Southeast Asia in order to transform the country into a global education center. The average education in the country accounted for $2.7 \%$ of GDP. Education Policy of Singapore has a number of features, among which I would like to highlight the following.

1. Preparation of workers carried out a predesigned and coordinated country-level plan to ensure industrial growth and avoid the disabled training office workers.

2. The state allocates to education and vocational training large subsidies.

3. The country allocation provided for talented graduates with regard to their ability. Thus $25 \%$ of graduates entering the university, and the rest - in vocational schools.
4. Educational activities focus on the training of scientific, engineering and technical personnel, specialists in finance and minimally focused on general subjects[9].

As the Analytical Review, the success of a single NUS - a synthesis of powerful external and internal factors, a combination which achieves the desired success. This opinion confirms the successful experience of other universities in the region, in particular following the popularity and performance rating - Peking University.

Peking University has been and remains one of the most prestigious universities and China and is considered a platform for implementing innovative ideas in the field of training. Peking University is the largest Chinese research university located in Beijing and a member of the C9 League. C9 League is an association of nine elite universities in China, AAC and similar Ivy League in the United States, Canada U15, Russell Group in the UK and Australia Go8. In the late 20th century, the Chinese government put Peking University on the top of his agenda for the development of higher education to create an excellent university in the 21 st century.

The current level of Chinese education system meets the highest international standards, as China's growing economy needs highly qualified specialists. It should be noted that despite the large number of Chinese population, which now exceeds 1 billion. 384 million. Residents[10], its central university does not belong to the category of the largest in the world by number of students. Faculty Beijing University has 5.513 teachers, including 52 members of the Chinese Academy of Sciences, 7 members of the Chinese Academy of Engineering, 1 488 professors, associate professors 1889. Total number of students according to 2012 amounted to 32.777 .

Chinese education in recent decades has made a huge leap forward, so that today it is almost no way inferior to European standards, with the exception of cultural and national characteristics. Studying at university is mainly in Chinese, which is why foreign students for admission must demonstrate a good knowledge of Chinese language, although students have a choice - to learn English or Chinese. However, studies on English programs costing twice as much. Chinese software engineering, business 
administration, medicine, economics and finance are highly valued and recognized around the world. Each year the Beijing University invited more foreign professors to collaborate on projects.

The university introduced academic qualifications are recognized by universities in almost all countries. For lectures students are invited worldrenowned professors and be able to teach successful business. Most of the world famous companies have their representative offices in Beijing, Shanghai, Hong Kong, given that there is a need for specialists who know a high-level Chinese language and have experience of living in the country.

China's current education system is focused on European standards, teachers use modern teaching methods and learning materials. The bulk of the training programs developed by Chinese experts, focused on the realities of the Chinese market, which generally has its own characteristics and different from the situation in Europe or the US. However, economic growth in China confirm the justification made steps. Thanks to the quality of educational programs, significantly increasing the number of foreigners who come to China to study programs MBA.

Similarly, popularity in China and to international ratings are Tsinghua University (THU). The University is leading in the "Engineering and Technology", taking in this direction 11 position in the world. At Tsinghua University educated over 34 thousand students, of which about one in 9 students is a foreigner [11]. The teaching staff of educational institutions has more than 5.000 teachers, among them foreign specialists.

It should be noted that the Chinese high school was built on the model of the former Soviet. Nevertheless, today's leading Chinese universities are among the top 30 in the world, and the best Ukrainian - not overcome and 300 positions. In this respect, not particularly distinguished and Russian universities.

We will try to analyze the situation in the historical aspects of the implementation of reforms. Of course, the success of the Chinese higher education institutions could reach not once, but in stages. Reform of China's higher education began with the 1980s, which led to a gradual improvement in the industry. Structural reforms consisted of five parts, including reforming the delivery of higher education of higher education, financing higher education. The most difficult reform turned recruitment, employment and internal management institutions. These reforms were designed to provide higher education institutions greater autonomy and the ability to meet the needs of students, despite the fact that the state solely focused on planning at the macro level.

The rapid development of China's higher education began in the late 1990s. In 1999, China took a course on the expansion of higher education over the next decade. The annual rate of increase in the number of students by $2 \%$ led to an increase in enrollment of applicants in 2012 compared to baseline by $30 \%$. According to official statistics, the Chinese higher education system consisted of more than 2442 ordinary (academically oriented) colleges and universities and 348 adult higher education and 823 are not academically oriented private agencies. Among the conventional higher education institutions, most, namely 1.623 were linked to provincial or local authorities, 113 were related to national ministries and had more funding and prestige, and 706 were from private financing and management. Structural universities in China, according to 2012 are presented in the tab. 1 .

Table 1

Higher education institutions in China in 2012

\begin{tabular}{|l|c|}
\hline \multicolumn{1}{|c|}{$\begin{array}{c}\text { The list of universities on the basis of } \\
\text { systematization }\end{array}$} & Quantity \\
\hline \multicolumn{2}{|c|}{ By the period } \\
\hline Conventional Universities & 2442 \\
\hline \multicolumn{2}{|c|}{ For membership } \\
\hline 4-year studying & 1145 \\
\hline From 2- to 3-year study & 1297 \\
\hline \multicolumn{2}{|c|}{} \\
\hline Subordinate to the central ministries & 113 \\
\hline Ministry of education & 73 \\
\hline Other central ministries & 40 \\
\hline Subordinate Provinces & 1623 \\
\hline Private & 706 \\
\hline Adult Universities & 348 \\
\hline Private agencies & 823 \\
\hline
\end{tabular}

Source: The National Bureau of Statistics of China (2012), http://data.stats.gov.cn/workspace/index; jsessionid $=$ C781D208E25C79B326BD B5A26F52CE16? $M=$ hgnd 


\section{O. Kuzmin, M. Yastrubskyy, H. Tsegelyk}

In 2012, China had a total enrollment of more than 31 million people, including 25.6 million in the usual higher education sector and nearly six million adults in the higher education sector. $1.7 \mathrm{~m}$. (5.5\%) were registered at postgraduate, 16.7 million. (53.2\%) studied a bachelor program and the remaining 13 million $(41.3 \%)$ were registered in two or threeyear programs. China surpassed the United States the number of students in universities and has the largest higher education system in the world. It is worth mentioning that the system of higher education in China is under constant development. In spite of the fact that the higher education in China is mainly public (state-owned), a private sector is developing very quickly. In this regard its organizational structure has been changing as well. According to the official data in 2014 there were 727 private institutes having right to issue the diploma and certificates, including 5 higher education establishments having right to train postgraduate students, 315 educational establishments offering a four-year program for the Bachelors training and 307 establishments offering a tree-year training program with the further issue of the certificates. Within the last ten years, the number of private higher education establishments in China has increased by 413 educational establishments.

The information about the higher education establishments in China according to the data of the year 2014 has been integrated into tab. 2 .

In general, according to the data of the year 2014, the institutes training students according to the short-cycle programs are designated for further training with the right to issue the certificates. Starting with the year 2001 there were more educational establishments having the right to confer the Bachelor's degree. They made $52,47 \%$ of the general amount of the higher education establishments.

Data on admissions China in 2012 are given in the tab. 3 .

Table 2

Chinese Higher Education Institutions according to the data of the year 2014

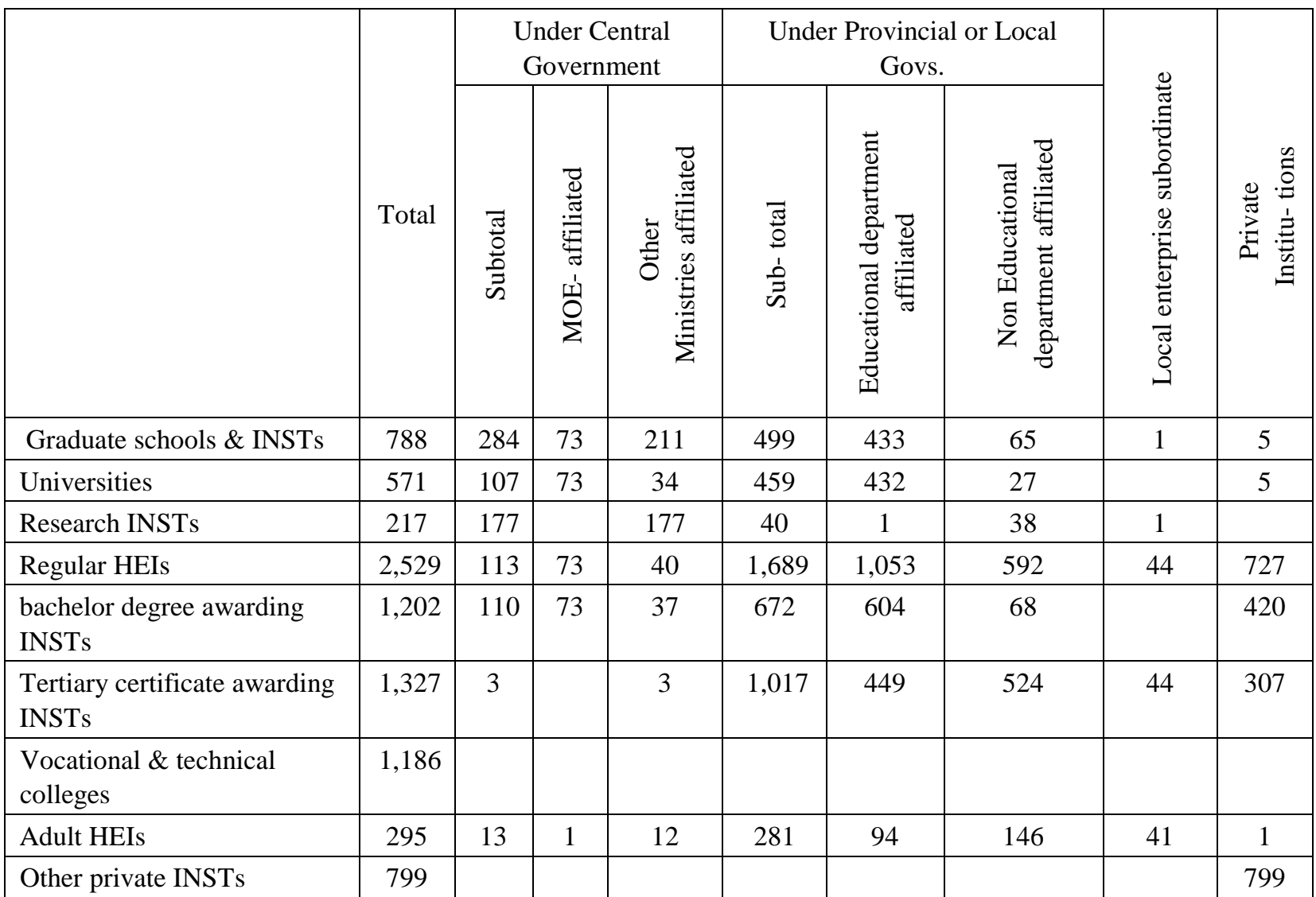

Source: http://data.stats.gov.cn/easyquery.htm? cn=C01 
Model of development and state regulation of activity of higher educational institution (hei): using...

Table 3

Admission to Universities of China in 2012

\begin{tabular}{|l|c|}
\hline \multicolumn{1}{|c|}{ List of universities and admission programs } & The contingent of students \\
\hline Ordinary Universities & 25.632 .973 \\
\hline Of them: & 1.719 .818 \\
\hline the Master's program: & 283.810 \\
\hline - doctoral level & 1.436 .008 \\
\hline - Master's level & 23.913 .155 \\
\hline for undergraduate programs & 14.270 .888 \\
\hline - 4-year university & 9.642 .267 \\
\hline - 2 - and 3-year-old university & 5.831 .123 \\
\hline Adult Universities & 2.475 .495 \\
\hline - 4-year university & 3.355 .628 \\
\hline - 2- and 3-year-old university & 31.464 .096 \\
\hline Total contingent & \\
\hline
\end{tabular}

Source: The National Bureau of Statistics of China (2012), http://data.stats.gov.cn/workspace/index;jsessionid = C781D208E25C79B326BD B5A26F52CE16?

Between 2012 and 2017, the number of institutions of higher education, as well as the number of students, increased significantly. Structural universities in China and total enrollment in higher education institution, according to 2017 are presented in the tab. 4 .

\section{Higher education institutions in China in 2017}

\begin{tabular}{|c|c|}
\hline $\begin{array}{l}\text { The list of universities on the basis } \\
\text { of systematization }\end{array}$ & Quantity \\
\hline $\begin{array}{l}\text { All together Higher Education } \\
\text { Institutions (HEIs) }\end{array}$ & 2631 \\
\hline Universities & 1243 \\
\hline - independent colleges & 265 \\
\hline Higher vocational colleges & 1388 \\
\hline $\begin{array}{l}\text { Higher education institutions for } \\
\text { adults }\end{array}$ & 282 \\
\hline \multicolumn{2}{|c|}{ Total enrollment of undergraduate (persons) } \\
\hline - in the regular HEIs & 27535869 \\
\hline $\begin{array}{l}\text { - of adult higher education } \\
\text { institutions }\end{array}$ & 5441429 \\
\hline \multicolumn{2}{|c|}{ Total enrollment of postgraduate (persons) } \\
\hline in the regular HEIs & 2639561 \\
\hline
\end{tabular}
hedu.php
With the purpose of assessment, there is calculated in China the gross enrolment ratio, which is determined as a part received after the division of the general amount of students studying at the higher education establishments to the general amount of population belonging to the corresponding age group. According to the state plan of secondary and long-term education development and the education reforming for the period of 2010-2020, the general enrolment ratio to 2015 equaled to $36 \%$ and in $2020-$ $40 \%$. However, at the end of 2014, the actual rated value reached the goal ahead of schedule, making $37,5 \%$. No doubt, the year 2015 was marked as an achievement of the epoch because there was reached $40 \%$ goal, which exceeded the average indices of the countries with the average income standard.

In 2014 a number of students studying according to the standard Bachelor's level made $25,48 \mathrm{mln}$., those studying at graduate courses $1,85 \mathrm{mln}$. and at the Doctoral program - 310,000. Only during the analyzed year, a number of students increased by 7,21 mln. of those newly enrolled. To the private higher education establishments in 2014, there were enrolled 5,87 million students, including 3,75 million of Bachelors and 2,12 mln. - to the educational establishments having the right to issue the certificates of higher education. The increasing amount of enrolled students in the private sector equaled to 930 000. But on June 2019, there were 


\section{O. Kuzmin, M. Yastrubskyy, H. Tsegelyk}

10.31 million students taking the National Higher Education Entrance Examination (Gao Kao) in China. Such statistics clearly demonstrates the practical implementation of the course of higher education massive involvement held in China.

It should be noted that in recent years China has significantly increased the contingent of foreign students. China agreed to gradually open its market to the world of education after joining the WTO in 2001. Under current law, foreign investors can manage educational institutions (senior schools, universities, colleges) in the form of joint Sinoforeign enterprises in which foreigners can be major shareholders. Compulsory education (primary and secondary) and specific education (Military, Police, religious) is not included here.

Thus, according to statistics in 2012 in Chinese universities enrolled 157.845 foreign students, 18259 of whom received academic degrees. In 2013, China became the most popular foreign students for countries in Asia and ranks third overall among all countries. On April 2019, Ministry of Education of the People's Republic of China announced a total of 492,185 international students were studying in China in 2018. International students have enrolled in over 1004 higher education institutions in China [12].

The Government has developed a recovery plan for education in the twenty-first century, which provides a course on mass higher education. Thus, the Chinese government pursued the goal of converting large system of high school in a strong higher education.

In 2010, a plan was developed national education reform and development in the medium and long term for the period 2010-2020. The document presented comprehensive measures to reform the educational sector, whose purpose is to improve the overall quality of higher education, promoting innovation, increasing internationalization. Particular attention is paid to the identification and selection of talented youth for training professionals improve the quality and consistency of scientific research. The document provides for the optimization of the overall structure of higher education and the development of its organizational uniqueness that addresses the needs of society under conditions of sustained economic development.

Chinese higher education is becoming more open in terms of international exchange and cooperation. Each year more than 300.000 Chinese students going abroad on student exchange programs with the purpose of education. China welcomes foreign students for higher education in China. International cooperation in higher education includes academic exchanges, cooperation in science and international exchange infrastructure. Some universities in China collaborating with leading universities of program creation and dissemination of new knowledge, exchange programs with scientists from other countries in major international scientific and technical cooperation, as well as in promoting cultural exchanges.

China to focus on increasing its international competitiveness of higher education, primarily in the form of Project 211 and Project 985.

Project 211, which is a planning document, intended to reform higher education to its development by taking concrete and strengthening of 100 higher education institutions in key disciplinary areas. As of 2013, the three phases of the project were implemented, covering 112 universities. The project took place under conditions of adequate financial support from the state. Only during the 1995-2005 biennium. Government allocated for the support of 211 organizations 36.8 billion. Yuan, accounting for 5.34 billion. US dollars. In 2019 investment in education accounts for about $4 \%$ of total GDP in China.

Project 985 was launched by the Chinese government to create world-class universities in the XXI century. It was approved and officially launched in 1999. Peking University and Tsinghua University were selected for the first implementation of Phase I of the project 985. At present, 39 universities included in Project 985, all of which are taken from those included in Project 211.

The project aims to replenish Chinese universities and world-class Universities ranks to the middle of this century, some of which are expected to be in the future global advanced research centers, which will be a prerequisite for achieving the goals of transforming China into an advanced developed countries. Financial support for the project from the state 985 was even greater.

Realizing the problem of mass higher education, China has paid special attention to creating a system of quality assurance. In 2003, the Ministry of Education has proposed an action plan 
for 2003-2007, which provides for activation of higher education every five years. In 2004, was created with the purpose of evaluating higher education Educational Assessment Center of Higher Education, Ministry of Education. Its creation marked the transition of China to a standardized, scientific, systematic and professional orientation educational work.

Currently, Chinese higher education is at a critical point of transformation. After the rapid growth of Chinese higher education is currently in a phase of sustainable development, with an emphasis on quality, fairness and restoring the balance between the number of graduates and the demand for them from the labor market.

\section{Model of building an effective system of higher education in Ukraine}

The development and state regulation of higher education in Ukraine is an area of innovation aimed at its quality rebirth. Improving the efficiency of the educational process in higher education is done in different ways. The result can be achieved by optimum choice of teaching methods, improvement of communicative relations between the teacher and the student, adherence to the students hygiene of mental work, proper organization of independent work of students, application of interactive and cooperative forms of organization of educational process, application of technical means and technologies of e-learning, etc.

During the period of independence, the Ukrainian high school has undergone many changes and transformations, but their polyvectority has led to the need for the next stage of reform - a radical restructuring. At the reform stage, it is very important to define the concept of transformation.

The harmonious development of universities is specific to each social group because it includes the active components inherent in the society in which their activity is carried out. Having done analysis of practical experience of leading national and foreign systems of education, one can proceed to the problem of construction of a model of development and state regulation of the HEI activity.To ensure high level of scientific and technological progress of Ukraine, the state has to take care of adequate financial support of those universities in the first turn that train experts in prestigious and promising majors.
Let us compose a mathematical model, on the base of which it is possible to determine how many specialists of the prestigious majors of each university has to graduate in order to guarantee general maximal efficiency of the specialists preparation.To do this, first it is necessary to determine the rating of each university for the training of specialists in prestigious majors.

We will determine rating of a university not by number of professors and associate professors involved in the academic process, but on the base of their quality. That is, we need to account for the certain period of time (e.g. for last five years) the following:

1) A number of publications in professional scientific journals;

2) A number of publications in foreign journals and the journals listed in scientometric bases;

3) A number of defended dissertations both the $\mathrm{PhD}$ and doctoral;

4) A number of published textbooks and manuals etc.

Let

$n$ - the number of universities capable of training specialists from a certain number of available set;

$m$ - the number of prestigious specialties included in the existing set;

$r_{i j}$ - rating of preparation of the specialist of the $j$-th specialty in the $i$-th university $\left(r_{i j}=0\right.$, if the $i$ th university does not prepare specialists in the $j$ - th specialty);

$c_{i j}$ - the cost of training the specialist of the $j$ th specialty in the $i$ - th university;

$V_{i}$ - the amount of funds allocated for the training of specialists of the $i$-th university;

$p_{j}-$ the need for specialists in the $j$-th specialty;

$x_{i j}$ - the number of specialists of the $j$-th specialty, which is planned to be prepared in the $i$-th university (required values).

The task is to plan the training of specialists in prestigious specialties so that the overall rating of training specialists is the highest. To compose a mathematical model of the problem, denote the prestigious specialties by natural numbers from 1 to $m$, and by $M_{i}$ we denote the ascending order of the 
subset of these numbers, which correspond to the specialties for which the specialists of the $i$-th university can prepare.

Then the mathematical model of the problem will look like:

$$
L=\sum_{i=1}^{n} \sum_{j \in M_{i}} r_{i j} x_{i j} \rightarrow \max
$$

under conditions

$$
\begin{aligned}
& \sum_{i=1}^{n} x_{i j}=p_{j}, j=1,2, \ldots, m ; \\
& \sum_{j \in M_{i}}^{n} c_{i j} x_{i j} \leq V_{i}, i=1,2, \ldots, n ; \\
& x_{i j} \geq 0, i=1,2, \ldots, n, j \in M_{i} .
\end{aligned}
$$

We show that this model can be reduced to a model of a transport problem.

Suppose that

$$
c_{i j}=\alpha_{i} \beta_{j},
$$

where $\alpha_{i}$ - depends on the university, $\beta_{j}$ depends on the specialty. Then the condition

$$
\sum_{j \in M_{i}} \alpha_{i} \beta_{j} x_{i j} \leq V_{i}, i=1,2, \ldots, n
$$

can be rewritten as

$$
\sum_{j \in M_{i}} \beta_{j} x_{i j} \leq \frac{V_{i}}{\alpha_{i}}, i=1,2, \ldots, n .
$$

Let us denote $\beta_{j} x_{i j}=y_{i j}$. Then

$$
\sum_{j \in M_{i}} y_{i j} \leq \frac{V_{i}}{\alpha_{i}}, i=1,2, \ldots, n \text {. }
$$

Because $x_{i j}=\frac{y_{i j}}{\beta_{j}}$, then the condition

$$
\sum_{i=1}^{n} x_{i j}=p_{j}, j=1,2, \ldots, m
$$

can be rewritten as

$$
\sum_{i=1}^{n} y_{i j}=p_{j} \beta_{j}, j=1,2, \ldots, m .
$$

The target function will take the form

$$
L=\sum_{i=1}^{n} \sum_{j \in M_{i}} r_{i j} \frac{y_{i j}}{\beta_{j}} \rightarrow \max .
$$

So we got a mathematical model of the transport problem

$$
L=\sum_{i=1}^{n} \sum_{j \in M_{i}} r_{i j} \frac{y_{i j}}{\beta_{j}} \rightarrow \max
$$

under the conditions

$$
\sum_{i=1}^{n} y_{i j}=p_{j} \beta_{j}, j=1,2, \ldots, m ;
$$

$$
\begin{gathered}
\sum_{j \in M_{i}} y_{i j} \leq \frac{V_{i}}{\alpha_{i}}, i=1,2, \ldots, n ; \\
y_{i j} \geq 0, i=1,2, \ldots, n, j \in M_{i} .
\end{gathered}
$$

The resulting transport problem can be solved using the potential method if the parameters of the problem are known. Using the above model, you can provide the training of professionals who are needed now or in the near future, based on the trends and prospects of national economy.

\section{Conclusions}

As a result of the review of the experience of the leading universities of East Asia may be noted that between the formations of the leading educational institutions in different countries there are a number of common characteristics.

1. A sign of the formation of advanced developed system of higher education in the countries of the East Asian region is the government support the reform process industry.

2. Financial support allocated under the development program perspective, developed at the state level.

3. The main emphasis made on the quality characteristics of the educational process.

4. Long-term development of higher education involves the synthesis of higher education, science and industry, which resulted in the creation of technoparks.

Noteworthy is another aspect of the process of reforming higher education in China - external factors and the environment. China's success in education is one of the consequences of the reforms of Deng Xiaoping, through which universities gain real autonomy; the most powerful research universities received government investment. Universities were allowed to establish joint ventures. Appeared opportunity to open private universities. In the process of reform was adopted as a basis the US education system. For training and accommodation of students created the proper conditions. In the process of modernization and development of higher education based on international experience was taken.

Overall development of higher education of the East Asian region deserves further study in view of the existing potential and success and effectiveness of development. For Ukraine, this study is very 
Model of development and state regulation of activity of higher educational institution (hei): using...

relevant, because in some issues, particularly in terms of premises, there are similarities, identical origins, and thus performance is quite likely. This is not a direct copy because success involves taking into account national and regional characteristics, mentality, and ideological orientation. However, taking into account these factors, combined with the best practices of world leaders in a designated area can be the key to its own success.

\section{References}

1. Vystup L. Hrynevych Kruhlyy stil «Priorytetni napryamy diyal'nosti $u$ haluzi osvity $i$ nauky». [Speech by L. Grinevich Roundtable "Priority Areas of Activities in the Field of Education and Science"] Retrieved from: https://www.youtube. com/watch? $v=m c 94 F 61$ Y fE [in Ukrainian].

2. Dopovid' rektora NTUU "KPI im. Ihorya Sikors'koho" akademika NAN Ukrayiny M.Z. Z.hurovs'koho na sesiyi naukovo-pedahohichnykh pratsivnykiv 30 serpnya 2016 roku. [Report of the rector of KPI them. Igor Sikorsky academician of NAS of Ukraine M. S. Zgurovsky at a session of research and teaching staff on August 30, 2016] Retrieved from: http://kpi.ua/report2016\#sthash.g91TNYnA.dpuf [in Ukrainian].

3. Yastrubskyy, M. YA. (2016) Finansove zabezpechennya avtonomnykh doslidnyts'kykh VNZ Ukrayiny $v$ umovakh reformuvannya [Financial support for autonomous research universities in Ukraine in the context of reform]. Lohistyka Logistics, 846, 191-196 [in Ukrainian].

4. Kuz'min, O.Ye., \& Yastrubskyy, M.Ya. (2017). Priorytetni napryamky finansuvannya VNZ: osoblyvosti vplyvu kontynhentu inozemnykh studentiv na rezul'tatyvnist' diyal'nosti [Priority
Areas for Financing Universities: Features of the Impact of Foreign Students Contingent on Performance] Menedzhment ta pidpryyemnytstvo $v$ Ukrayini: etapy stanovlennya i problemy rozvytku: zbirnyk naukovykh prats'. - Management and entrepreneurship in Ukraine: stages of development and development problems, 862, 139-144. [in Ukrainian].

5. Zayachuk, M.D. \& Chubrey, O.S. (2009). Ekonomichna ta sotsial'na heohrafiya svitu: navch. posibnyk [Economic and social geography of the world] Chernivtsi: Chernivets'kyy nats. un-t. [in Ukrainian].

6. Reyting universitetov mira 2016 [ranking of universities in the world 2016]. Retrieved from http://total-rating.ru/1609-reyting-universitetovmira-2016.html [in Russian].

7. Nacional'nyi universitet Singapura. [National University of Singapore] Retrieved from https://www.unipage.net/ru/national_university_of _singapore [in Russian].

8. Investitsionnaya sistema Singapura [Singapore Investment System] Retrieved from http://globuss24. ru/doc/investicionnye-sistema-singapura [in Russian].

9. Public Finance Case Study Singapore. Retrieved from https://docviewer.yandex.ua/view/331206433/?*.

10. Naselenie Zemli. Schetchik naseleniya Kitaya. [Earth population. China population meter.] Retrieved from http://countrymeters.info/ru/World [in Russian].

11. Universitet Tsinhua [Tsinghua University]. Retrieved from http://www.new-asian.ru/education/ china/102/ [in Russian].

12. National Bureau of Statistics of China. Retrieved from http://data.stats.gov.cn/workspace/index; jsessionid $=C 781 D 208 E 25 C 79 B 326 B D$ B5A26F52CE16? $m=$ hgnd 